\title{
On the Occurrence of Natural Norway Spruce Woodland in the Pieniny Mts (Western Carpathians)
}

\author{
Peter KUČERA* \\ Botanical Garden, Comenius University in Bratislava, Blatnica, Slovak Republic
}

\begin{abstract}
According to Kulczyński (1928), a natural Picea abies forest occurs in the mountain range of the Pieniny Mts on the slopes of the mountain Vysoké skalky. Later, various data on the altitudinal range of this stand (and thus on the locality itself) were published: (1) 890 (900) - $950 \mathrm{~m}$, (2) $1000-1050 \mathrm{~m}$ or (3) around $1000 \mathrm{~m}$. The aim of the field research was to verify published data on the occurrence of an Upper Mountain Norway spruce woodland (association Polysticho-Piceetum) in the territory of Vysoké skalky. A field study in the area has revealed that most of published data on the occurrence of the Kulczyński's Picea woodland are incorrect, as its real upper altitudinal limit reaches $\pm 940 \mathrm{~m}$. The main result is the confirmation of the real existence of a Vaccinium myrtillus-Homogyne alpina-Picea abies phytocoenosis in the territory of Vysoké skalky. However, tree species other than Picea abies (e.g. Fagus sylvatica, Abies alba, Acer pseudoplatanus) could persist in the special habitat of Kulczyński's 'Picea woodland'. The natural vegetation of this place was formed by mixed forest stand.
\end{abstract}

Malé Pieniny Mts / Picea abies woodland / phytosociology / Polysticho-Piceetum / Vysoké skalky

Kivonat - A közönséges luc természetes állománya a Pieninekben (Nyugati-Kárpátok). Kulczyński (1928) természetes lucos állomány el fordulását jelezte a Pieninek montán régiójában (a Vysoké skalky csúcs térségében). A kés bbiekben ezen állomány tengerszintfeletti magasságáról (s egyáltalán elhelyezzkedésér 1) különböz adatokat közöltek: (1) 890 (900)-950 m, (2) 1000-1 050 m vagy (3) $1000 \mathrm{~m}$ körül. A terepi kutatások célja a montán lucfenyves társulás (Polysticho-Piceetum) el fordulásának felülvizsgálata volt a Vysoké skalky térségében. A vizsgálatok rávilágítottak arra, hogy a Kulczyński-féle állományra vonatkozó adatok többsége téves. A felmérés meger sítette egy Vaccinium myrtillus-Homogyne alpina-Picea abies növényközösség el fordulását a területen (ennek fels elterjedési határa $940 \mathrm{~m}$ tszf. m. körül található), azonban súlypontos más lombos fafajok (pl. Fagus sylvatica, Abies alba, Acer pseudoplatanus) el fordulása is a térségben, azaz a természetes erd társulás fetételezhet en egy montán, lombelegyes fenyves lehetett.

Kis-Pieninek / Picea abies állományok / növénytársulástan / Polysticho-Piceetum / Vysoké skalky

\section{INTRODUCTION}

A distinct feature of the landscape of higher mountain ranges of the Western Carpathians is formation of a separate altitudinal vegetational zone dominated by native Picea abies forests (class Piceetea excelsae Klika 1948). According to the different ecological conditions and corresponding floristical variance, several associations were described that are divided into

\footnotetext{
*peter.kucera@uniba.sk; Blatnica 315, SK-038 15 Blatnica pri Martine
} 
two major groups (Kučera 2012a): (A) Piceetalia excelsae Pawłowski ex Pawłowski et al. 1928 on generally nutrient-poor acidic substrates and (B) Athyrio filicis-feminae-Piceetalia Hadač ex Hadač et al. 1969 on calcareous substrates. In the Slovak part of the Western Carpathians, seven associations among the two major groups of Picea abies-dominated plant communities are currently recognised in the present (Kučera 2012a): (A) Vaccinio myrtilliPiceetum, Athyrio alpestris-Piceeetum, and Chrysanthemo rotundifolii-Piceetum and (B) Seslerio variae-Piceetum, Corthuso matthioli-Piceeetum, Adenostylo alliariae-Piceeetum excelsae, and Oxalido acetosellae-Piceetum. In the Polish phytocoenological literature there are two traditionally differentiated units of supramontane Picea abies-dominated communities (see J. M. Matuszkiewicz 2002): Plagiothecio-Piceetum tatricum (name is validly published only with the epithet 'tatricum'; a syntaxonomic synonym to Vaccinio myrtilli-Piceetum Šoltés 1976) and Polysticho-Piceetum (a syntaxonomic (heterotypical) synonym to Oxalido acetosellae-Piceetum Březina et Hadač in Hadač et al. 1969 (Kučera 2012a)).

The first evidence of the existence of a native Norway spruce stand (Picea abies) in the Pieniny Mts was published by Kulczyński (1928) in the famous work The plant associations of the Pieniny. This author gave a short introduction to the differentiation of Carpathians' forests into altitudinal vegetation zones and pointed out that the typical form of Picea abies forests could also exist out of the elevation range $1200-1550 \mathrm{~m}$ (i.e. altitudinal range usually considered as a territory of native supramontane Picea abies forests) as a result of natural conditions.

In the Pieniny Mts, reaching up to only $1049.8 \mathrm{~m}$ (Vysoké skalky/Wysokie Skałky/Wysoka in the eastern part of the Pieniny Mts - the so-called Male Pieniny/Małe Pieniny), he found an example of such 'extrazonal' occurrence, which he regarded as a natural phytocoenosis:

"Auf dem Gebiete des Pieniny-Zuges tritt der natürliche Fichtenwald nur an einer einzigen Stelle, unterhalb des Gipfels »Wysokie Skałki«, in einer Höhe von ca. 900 ü. M. auf. Er ist als ein kleines Assozioationsindividuum von einigen Hektaren Oberfläche ausgebildet." (Kulczyński 1928, p. 119).

A very brief description and evaluation of this stand situated at the Polish slopes of Vysoké skalky is followed by a complete listing of species found in the whole stand, with cover-abundance values (Kulczyński 1928, p. 119-120).

To date, I have not found published phytosociological relevés from the area of Kulczyński's Picea stand of the Malé Pieniny in the available literature sources. Later authors have only mentioned occurrence of a special vegetation type of Picea abies in the Pieniny Mts, mostly without reference to Kulczyński (1928). J. Matuszkiewicz (1977) evaluated Kulczyński's stand within the association Polysticho lonchitidis-Piceetum W. Matuszkiewicz ex J. Matuszkiewicz 1977 and utilized the data of Kulczyński (1928) as a "phytosociological relevé' (see Results).

Reference to the occurrence of the association Polysticho-Piceetum in the Pieniny Mts was repeated by W. Matuszkiewicz $(1982,2014)$, W. Matuszkiewicz - J. M. Matuszkiewicz (1996) and J. M. Matuszkiewicz (2002). In contrast, Medwecka-Kornaś (1959, 1972) did not include the Pieniny Mts in the list of mountain ranges with occurrence of a vegetation type of Norway spruce in her overview of woodland and scrub communities of Poland.

Localization of the occurrence of the Picea abies stand under consideration (Malé Pieniny, on the slope of Vysoké skalky) varies in the publications. According to the first author, Kulczyński (1928), his hectares of Piceetum excelsae occur in the elevation ca. $900 \mathrm{~m}$. In the chapter of Zarzycki (1982, Tab. I), the altitudinal range of Piceetum excelsae occurrence is limited to elevations of $890-950 \mathrm{~m}$. The same values are given in Tab. I by Zarzycki (1981, p. 14), although in the text (p. 32) the indicated values are 900-950 m.

A somewhat different place is given by W. Matuszkiewicz (1982, p. 216-217, Polysticho-Piceetum; 2014): in the elevation ca. 1000-1050 m below the summit of 
Wysokie Skałki. This location was apparently followed by Szeląg (1995) as he wrote that Polysticho-Piceetum occurs only in the summit part of the Wysokie Skałki, at the elevation 1000-1 $050 \mathrm{~m}$. In the same book as Zarzycki (see above), Pancer-Kotejowa et al. (1982, p. 319) mentioned an elevation 'around $1000 \mathrm{~m}$ '.

In the third group of works, there is no exact elevation range in metres given, e.g. J. Matuszkiewicz (1977): on the highest summit of the Malé Pieniny; Pancer-Kotejowa et al. (1982) on page 325 did not give exact data on location (see above).

In respect to the overall distribution of natural non-mixed Picea abies forests in the Western Carpathians (Matuszkiewicz 2002, Kučera 2012a, cf. Kulczyński 1928, p. 118), published data on the occurrence of a natural Picea abies community in the Pieniny Mts are very interesting. Such a unique existence was probably one of the reasons why this area is under protection in the form of a nature reserve, declared several decades ago. As the original data was published only by Kulczyński (1928), I was drawn to understand the nature of such special Piceetum ocurrence to supplement my knowledge of Western Carpathians' Picea abies woodlands and to gain field experience and data by myself. Verification of published data on the occurrence of a natural Norway spruce woodland in the territory of Vysoké skalky was the aim of the undertaken research: its results are presented in this paper.

\section{MATERIAL AND METHODS}

Phytosociological relevés were carried out in the year 2011 in cover-abundance scale in terms of Braun-Blanquet (1951) and extended with degrees $2 \mathrm{a}$ and $2 \mathrm{~b}$ according to Barkman et al. (1964) (cf. Westhoff - van der Maarel 1973). Examples of the recorded phytocoenoses (7 phytosociological relevés) are given in the Appendix. Coordinates (WGS-84) were obtained with the device GPSMAP® 60CSx in addition to a hiking map of Pieninský národný park (2001). The age and height of trees was estimated (cf. notes in Kučera 2013). Nomenclature of the vascular plants and bryophytes follows the lists of Marhold et al. (1998) and Kubinská - Janovicová (1998). Collected specimens of bryophytes (herbarium BBZ) were determined by Mgr A. Petrášová and chosen vascular plants by RNDr D. Bernátová, CSc. The programs Turboveg for Windows (Hennekens 2012) and JUICE (Tichý 2012) [cf. Hennekens - Schaminée 2001, Tichý 2002] were used for the processing of phytosociological relevés.

\section{RESULTS}

\subsection{Actual vegetation conditions of forests at Vysoké skalky}

In fact, the uppermost part of the slopes of Vysoké skalky is not covered by stands of Picea abies. A substantial part of the cited elevations $1000-1050 \mathrm{~m}$ (see Introduction) is occupied by a compact summit rock, available without climbing only from the northwest side from a very short ridge with the lowest elevation $1032 \mathrm{~m}$. Above that only spurs of Fagus sylvatica forest reach, and the highest situated trees are of Sorbus aucuparia, Fagus sylvatica and Acer pseudoplatanus (with Coryllus avellana, Sambucus racemosa, Salix caprea, Cotoneaster integerrimus, Ribes alpinum).

Adjacent slopes on the Slovak part of the state border (running along the main ridge of the mountain range) are covered by climax deciduous forests dominated by Fagus sylvatica; Acer pseudoplatanus is admixed, I noticed saplings of Abies alba and also several Picea abies trees. Cultures of Picea abies spread below the summit of Vysoké skalky in lower altitudes only. 
A similar picture appears on the Polish slopes of the area around the summit of the Vysoké skalky. Notable is a treeless gap to the northeast between summit rock walls and the upper forest line reaching around $1029 \mathrm{~m}$ a.s.1. $\left(49^{\circ} 22,833^{\prime} \mathrm{N}, 20^{\circ} 33,333^{\prime} \mathrm{E}, \pm 6 \mathrm{~m}\right)$. Forest stands are dominated by Fagus sylvatica as demonstrated by phytosociological sample No. 1 (see Appendix).

To the east of the relevé plot No. 1, the field layer has a more grassy character (Hordelymus europaeus) and onward is without Lunaria (with Aconitum moldavicum [cf. Kučera 2011], Cimifuga europaea). Above the upper edge of the relevé plot No. 1 no stand of Picea abies grew in the past: located there is a group of three dead Picea abies trunks only, and several other Picea trees are scattered in the beech forest in the vicinity of the relevé No. 1.

Nevertheless, there is one stand of Picea abies close to the summit of Vysoké skalky (Figure 1: A). It is formed as an island inside of a beech forest and its upper limit reaches to elevation ca. $1020 \mathrm{~m}$ (below the northwest ridge of the Vysoké skalky) and its lower limit to ca. $950 \mathrm{~m}$. This stand was severely disturbed some years ago (before 2010) and today contains only a small portion of living Picea abies trees.

The herb layer and the entire spread of this former Picea abies island is marked by dominant Rubus idaeus, while a field layer of the adjacent beech areas under the summit ridge is made up of various vegetation types (Galium odoratum, Asarum europaeum, Oxalis acetosella [Polygonatum verticillatum, Senecio ovatus, sparsely Rubus idaeus of lower growth etc., also saplings of Acer platanoides] or Dryopteris filix-mas, Galium odoratum, Lunaria rediviva or below the summit Lunaria rediviva, Dryopteris filix-mas [Lonicera nigra, Sambucus racemosa, Dentaria glandulosa]). The most remarkable feature of the canopy of this Picea abies island (Figure 1: A) is the equal age of the trees (age class ca. 60-80 years): the stand is a planted monoculture. Also, the overall natural conditions (e.g. soil, climate) of mentioned Picea-vs. Fagus-dominated adjacent stands are more or less the same: the most important factor that differentiated the development of the undergrowth of the respective stands was the presence or absence of an anthropic influence $=$ the plantation of Picea abies .

Similarly differentiated is another Picea abies island (Fig. 1: B) lying west of coordinates $49^{\circ} 22,859^{\prime} \mathrm{N}, 20^{\circ} 33,277^{\prime} \mathrm{N}( \pm 6 \mathrm{~m}, 1027 \mathrm{~m})$, with a lower elevation limit of $964 \mathrm{~m}\left(49^{\circ} 22,916^{\prime}\right.$ $\mathrm{N}, 20^{\circ} 33,197^{\prime} \mathrm{E}, \pm 12 \mathrm{~m}$ ). In the same manner as the previous one, it has artificial borders to the adjacent Fagus stands. This Picea abies stand-island was also planted by man less than ten decades ago (up to ca. 60-80 years). Part of the Picea trees was also wind-blown and another part died after a recent parasite infestation, but the rest Picea trees have survived. The area of the windthrow is overgrown by Rubus idaeus and Senecio nemorensis agg. Today there is admixed Fagus sylvatica, which rejuvenates (I noticed also a sapling of Abies alba in the stand's border). A potential rejuvenation of Picea abies is blocked here by rich secondary undergrowth: this subpopulation (as well as the previous one) will not survive a natural development of the vegetation cover.

Also the last of the Picea abies stands below the summit of Vysoké skalky on the Polish side of the state border slopes, neighbouring upon recent pastures (Figure 1: C, prevailing area between elevations 910-940 m), is a plantation, nowadays mostly destroyed by wind (Rubus idaeus is the dominant plant species recently).

Further apart from the summit of Vysoké skalky to the northwest, there are other Picea abies stands (Figure 1: D-E, F). Finally, in the area of the stand marked as 'D', I could confirm the data of Kulczyński (1928, p. 119) regarding the existence of Picea abies woodland with an herb layer dominated by Vaccinium myrtillus, with occurrence of Homogyne alpina and also Vaccinium vitis-idaea. Its elevation range is ca. $870-940 \mathrm{~m}$. This unique vegetation is induced by thin soil cover developing on special bedrock - carbonate hill debris with boulders frequently reaching dimensions of $40 \times 40 \mathrm{~cm}$. Debris boulders are not weathering much so the corresponding habitat is very conservative. Uprooting of trees reveals bare boulders of hill debris. 


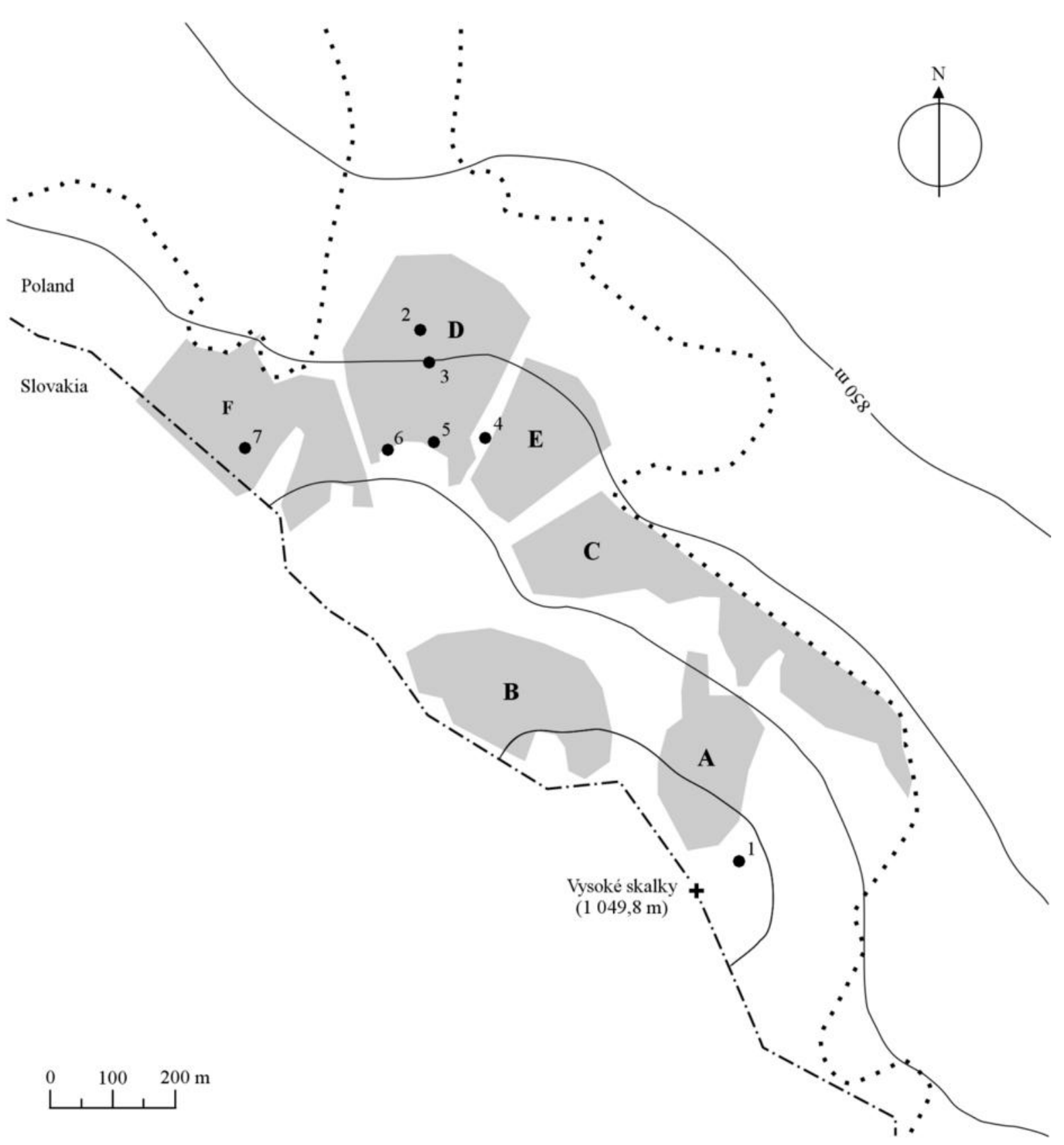

Legend:

Individual areas of Norway spruce growth $(\mathrm{A}-\mathrm{F})$ in the territory of Vysoké skalky

... Border of current woodland

- - State border between Slovakia and Poland

Contour lines, interval $50 \mathrm{~m}$

- Sites of phytosociological relevés No. 1-7 (see Appendix)

Figure 1. Sketch map of the locality

However, also here a great part of Picea abies population was attacked by parasites (before 2010) and died. Insect attack was most probably preceded by wind disturbance of this and other stands in the vicinity. However, a sufficient amount of Picea trees resisted and survival of this population is ensured by rich natural rejuvenation of Norway spruce with variable age spans, and forming thickets here and there. An example of the vegetation type is given by the phytosociological relevé No. 2. The lateral border of Vaccinium myrtillus-Homogyne alpina- 
Picea abies woodland to the former original beech forest is indicated by typical herbaceous facies of beech woodlands (Galium odoratum [also dominant], Asarum europaeum, Symphytum cordatum, or Astrantia major, Petasites albus; also Cicerbita alpina and Streptopus amplexifolius grow here (site of the last species: 49 $23,001^{\prime} \mathrm{N}, 20^{\circ} 33,097^{\prime} \mathrm{E}, \pm 7 \mathrm{~m}$, $930 \mathrm{~m})$ ) and the absence of Vaccinium myrtillus. The background here at the hill debris border could also be formed by carbonate debris, but the size of the rocks is considerably smaller and the soil profile is deeper than in habitat of Vaccinium myrtillus-Homogyne alpina-Picea abies woodland.

Above the upper right corner of the relevé plot No. 2, vegetation with Hypericum maculatum, Deschampsia cespitosa, Agrostis capillaris, Taraxacum sp. is growing. This occurrence indicates an influence of the former pasture.

According to Kulczyński (1928, p. 118-119), this area is home of a native Picea abies woodland. However, despite the special habitat conditions, trees of Fagus sylvatica could also grow and prosper here and could withstand windstorms. In the vicinity of the relevé plot No. 2, an older Fagus tree (more than 60-70 years) is growing and it is a source for (microlocally considerably rich) the rejuvenation of Fagus. Such a vegetation sample is given in relevé No. 3, spatially only $10 \mathrm{~m}$ from the relevé plot No. 2 . The prevailing part of the Picea trees on the plot was windblown, other parts died after parasite attack; Fagus grow successfully.

However, even Fagus can dominate in the canopy in this debris territory. The next relevé (No. 4) was recorded on the lateral debris ridge, with rocks on the surface. A different vegetation type is developed here.

To the east of the relevé plot at the slope beginning down from this lateral ridge, hill debris and communities with Vaccinium myrtillus cover the slope in the same manner as west of the ridge (Figure 1: D). Lonicera nigra is abundant, rejuvenation of Picea abies is rich under the parasite-attacked and wind-blown Picea trees (Figure 1: E). Also, an old Abies alba tree was recorded (below coordinates $49^{\circ} 22,986^{\prime} \mathrm{N}, 20^{\circ} 33,224^{\prime} \mathrm{E}, \pm 9 \mathrm{~m}, 930 \mathrm{~m}$ a.s.l., here also an example of secondary, temporary occurrence of Cotoneaster integerrimus, see in Discussion): this tree species should be included among species that once co-determined the original woodland type. Secondary succession is here in a more advanced phase as in the stand marked in the Figure 1 as 'D'.

The original course of the upper limit of the local natural occurrence of woodland with abundant Picea abies is hard to determine today. Picea abies was propagated by human intervention directly (plantation) or indirectly (spreading by secondary succession). Relevé plot No. 5 is probably one of the highest points mixed woodland with Picea abies could reach originally. Today, a great part of the former Picea stand has been destroyed however, its population will persist as the species has rejuvenated long ago. An older Fagus tree uphill above the releve plot is the origin of the numerous beech saplings (with cover-abundance value 4 [-5]), a different habitat is indicated there by Sanicula europaea (richly), Primula elatior, Symphytum cordatum, Ranunculus platanifolius, Mercurialis perennis, Galium odoratum (Pulmonaria obscura). Originally there was already abeech woodland developed here.

The recent vegetation cover in the western uppermost part of the Picea stand ' $\mathrm{D}$ ' is interesting. Under dead Picea trunks, a rich undergrowth of Lonicera nigra and Vaccinium myrtillus grows. The slope relief indicates that hill debris is still 'living'. In the geological history, hill debris of 'stand D' probably originated through the collapse of solid rock. In the uppermost, rocky part of the hill debris, with formation of small rock walls and falling rocks and boulders (in the other place, we have seen also a small vertical cavern: $49^{\circ} 22.953^{\prime} \mathrm{N}$, $20^{\circ} 33.167^{\prime} \mathrm{E}, \pm 7 \mathrm{~m}$ ), wind and parasite disturbance caused all mature Picea specimens to die out and only young ones are living. However, the Fagus population here (relevé plot No. 6) 
could also grow successfully, supplemented with rejuvenation from trees growing uphill. After Picea died out, treeless scrub vegetation partly developed. The uppermost edge of the hill debris begins slightly higher. There, under tall Fagus trees, a Vaccinium myrtillus population is still growing, but only of a dwarfed growth. Further uphill there is distributed typical beech vegetation of deeper calcareous soils.

The last Picea abies stand in the Polish part of the territory of Vysoké skalky, marked on Figure 1 by the letter ' $\mathrm{F}$ ', is again a plantation. It continues directly to a younger spruce plantation (age 40-60 years) on the Slovak part of the state border. Relevé No. 7 shows clearly striking differences in the herb layer in comparison to relevés 2, 3 and 5. Also, nonindigenous species Larix decidua was planted here.

\subsection{Formal comments on the association Polysticho-Piceetum and data on its occurrence at Vysoké skalky}

The correct association name completed according to Recomm. 10C of the International Code of Phytosociological Nomenclature (ICPN: Weber et al. 2000) is Polysticho lonchitidisPiceetum W. Matuszkiewicz ex J. Matuszkiewicz 1977 (see Kučera 2010, who also designated a lectotype to the association). Yet, phytocoenoses of Kulczyński's Vaccinium myrtillus-Homogyne alpina-Picea abies woodland (see above) do not correspond to this syntaxon as well as to its probable syntaxonomical synonym Oxalido acetosellae-Piceetum Březina et Hadač in Hadač et al. 1969.

Also questionable is the utilisation of Kulczyński's (1928) phytosociological data on 'Piceetum excelsae' as a phytosociological relevé; for example, in the synthesis of J. Matuszkiewicz (1977). In contrast to other species lists in the work of Kulczyński, the species listing on pages 119-120 (Kulczyński 1928) should not be accepted as a constancy table nor as a single relevé by reason that it is a list of all species found in the whole area of the occurrence of the Picea abies stand extending up to 'several hectares' (see Kulczyński 1928 , p. 119), only accompanied with cover-abundance values. Therefore, the name proposed by Kulczyński - i.e. Piceetum excelsae Kulczyński 1928 - is to be nomenclaturally treated not only as a nomen illegitimum (ICPN Art. 31), but also primarily as a nomen invalidum (Art. 2b $\rightarrow$ Art. 7).

\section{DISCUSSION}

As shown above, there exist more than one Picea abies stand in the teritory of Vysoké skalky (Figure 1: A-F). The elevation range of both Picea abies stands 'A' and 'B', reaching continuously down to $950 \mathrm{~m} / 964 \mathrm{~m}$, considerably exceed the altitudinal limits of 1000-1050 m given by Matuszkiewicz $(1982,2014)$ and Szelag (1995) for natural occurrence of a Polysticho-Piceetum stand. As no such Picea abies stands on the slopes of Vysoké skalky exist, these published data should be taken as incorrect. In addition, occurrence of several Picea abies trees in the vicinity of the relevé No. 1 could not be the reason for the publishing of such data on occurrence of a native Norway spruce woodland in the summit area of Vysoké skalky.

In respect to elevation range of the stands 'A' and 'B', more closely fitting would be the information of Pancer-Kotejowa et al. (1982, p. 319: around $1000 \mathrm{~m}$ ), which could be applied to both Picea abies stands under consideration (Figure 1: A, B). Nonetheless, their species composition is completely different from the phytosociological data of Kulczyński (1928, see p. 119-120). The same stands for the species composition of Picea stands are labeled in Figure 1 as ' $\mathrm{C}$ ' and ' $\mathrm{F}$ '. 
On the other hand, the real existence of a Vaccinium myrtillus-Homogyne alpina-Picea abies community in the territory of Vysoké skalky (Kulczyński 1928) was indeed confirmed (see relevé No. 2, within the Picea abies stand 'D'). Field occurence of this vegetation type corresponded exactly to the place of Piceetum excelsae indicated by Kulczyński (1928) in his phytosociological map of the Pieniny. Kulczyński (1928, p. 119) is at the same time almost the only one who published correct information on its distribution; the second person was Zarzycki $(1981,1982)$ with elevation data 900-950 m resp. 890-950 m.

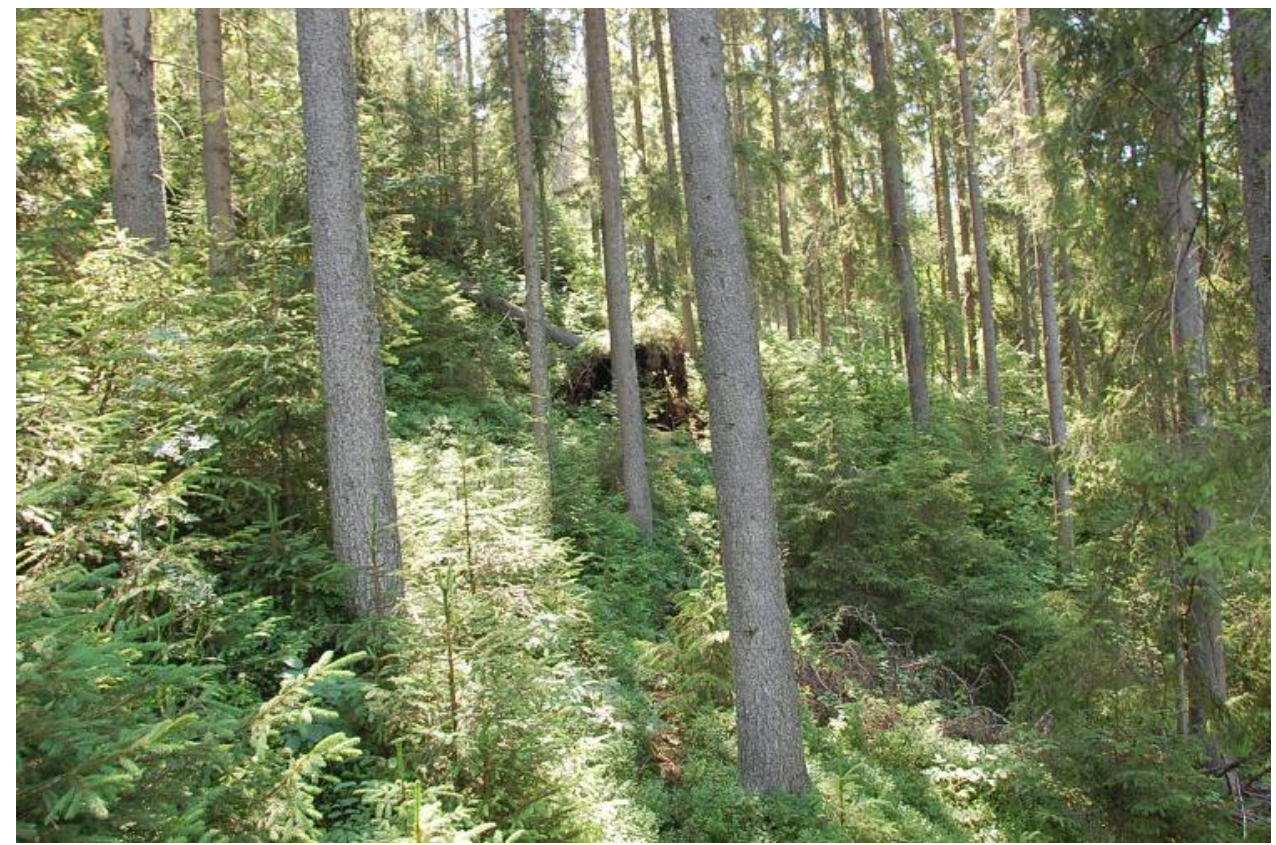

Figure 2. Plant cover in the site of the relevé No. 2.

Among all other Picea stands of Vysoké skalky, the area of the stand ' $\mathrm{D}$ ' is the one that provides a sustainable existence of the Picea abies population, including interspecific competition. This is due to a special conservative debris habitat. In my opinion, the stand marked in the map (Figure 1) as ' $\mathrm{E}$ ' is also an example of the refugium habitat of the Picea abies population: the total area of the natural occurrence of Picea abies in the territory of Vysoké skalky is thus larger than Kulczyński (1928) suggested in his phytosociological map.

However, the phytosociological sample No. 3 confirms that the locality described by Kulczyński (1928, p. 119) is not an example of the authentic Picea abies forest. The situation of species composition described by Kulczyński (1928) has its origin in long-term historic land use, deforestation of the prevalent territory of slopes of Malé Pieniny mountain ridge, and changes in species composition of woodland rests. Also, the species list of Kulczyński (1928) confirms the appearance of species with human-influenced distribution, 'aliens' in the originally common woodlands of this area: Antennaria dioica, Hypericum maculatum, Potentilla erecta, Cruciata glabra (Veronica chamaedrys; Cotoneaster integerrimus from secondary, temporary lighting of the stand).

Recent development of vegetation cover point to more-balanced mixed stands of Picea abies and Fagus sylvatica in the future. Thus, in contrast to Kulczyński (1928) and data of other authors on the natural existence of an autochthonous Picea abies plant community (see Introduction) in the territory of Vysoké skalky, I am of the opinion that the existence of Picea abies in this locality should be evaluated more likely as an isolated local relict of the Picea abies population persisting within forest of mixed tree species composition. Constant special habitat conditions are confirmed by remarkable co-occurrence of dominant Vaccinium 
myrtillus and $V$. vitis-idaea at the first place, Homogyne alpina and Calamagrostis villosa. In contrast to all other Picea stands (plantations) in the territory of Vysoké skalky, a gradation of Rubus idaeus does not occur.

\section{SIGNIFICANCE OF PICEA ABIES OCCURRENCE AT VYSOKÉ SKALKY}

If the population of Picea abies of the stands ' $\mathrm{D}$ ' and 'E' (Figure 1) is really a native (thus relict) population, then it could have developed most likely a unique, isolated gene pool. Genetic studies of possible differences compared to the closest native stands (Tatry Mts) should be considered. Picea abies forests predominated in the landscape of northern Slovakia in early Holocene (cf. Jankovská 1991, 1998). In the lower mountain ranges adjacent to the Tatry Mts there is reconstructed a potential natural vegetation consisting of Abies-Fagus forests (cf. Kučera 2012a, b; see also Kučera 2015): the Picea abies woodland of Vysoké skalky in the Malé Pieniny Mts was separated from the closest native Picea abies populations in the Tatry Mts during the Holocene (cf. Krippel 1963, 1986) by natural beech and fir-beech forests of the territory of Pieniny and the Spišská Magura Mts. Current Norway spruce stands covering large areas of both mountain ranges are results of long-term anthropic influence (see below).

Long-term isolation of the Picea abies population of Vysoké skalky could also lead to a particular adaptation to ecological conditions of the lower montane vegetation zone, which has special importance for forestry. However, the existence of Norway spruce cultures of uncertain provenience in the vicinity of Picea abies population of the stands ' $D$ ' and ' $E$ ' is a threat to preservation of the supposed original genotypic and phenotypic features.

Picea abies individuals and stands originated by plantation and saplings/young trees from their rejuvenation should be strictly regulated above all in the area of the Nature Reserve Wysokie Skałki. Also, spruce plantations west of this nature reserve should not directly influence the genetic composition of the above-mentioned relict population.

\section{REMARKS TO PICEA ABIES OCCURRENCE IN THE SURROUNDINGS OF VYSOKÉ SKALKY}

In the wider surroundings, we have also noticed a recent plantation of Norway spruce (cf. also Pawłowski 1925). However, as we can see in the territory of Vysoké skalky, plantations of Norway spruce are very vulnerable cultures in these low altitudes of the Malé Pieniny. Economic profit here is insecure because of the lability of tree stands and strong predisposition of Picea abies stands to disturbance (even total elimination) by wind and insect attacks.

Besides the plantation of Norway spruce, on the recent borders of pastures to forest in the Malé Pieniny, easy rejuvenation of Picea abies is in progress here and there. This is a typical form of a secondary succession, a spontaneous process of the spreading of forest back to its original place. In the lower altitudes, in a lower montane altitudinal vegetation belt, the first and long-lasting stage (in several phases) is formed by Picea abies (cf. Myczkowski Grabski 1962) if a 'parent' Picea abies stand (plantation) is in the surroundings. A secondary succession of Fagus sylvatica in such secondary, substitutional Picea stands could only be seen much later (cf. Kučera 2012a, chapter 4). However, long-term natural competition between Picea abies and other plant species generally results in the elimination of Picea abies in the lower montane belt. It seems that this rule has the one and only exception in the 
whole region of the Malé Pieniny - a population of Picea abies within the Kulczyński's (1928) stand of 'Piceetum excelsae' is maintained by special habitat conditions.

Except for such special cases, anthropogenic changes of the vegetation cover (direct or indirect) are the reason of the occurrence or even dominance of Picea abies in forest stands of the Pieniny Mts. According to my evaluation (cf. Kučera 2007, 2012b), stands evaluated as Piceo-Abietum carpaticum by Kulczyñski (1928) also originated by a spontaneous secondary succession, related to the planting of Picea abies (or direct plantation establishment) and the historical land use in the centuries before 1900 (see distribution of this plant community on his phytosociological map and extent of deforested area in the early 20th century); nomenclatural status of the name: Piceo-Abietetum carpaticum Kulczyński 1928, nom. inval., ICPN Art. 3e (Weber et al. 2000). In the adjacent mountain range of the Spišská Magura, superiority of Fagus sylvatica (Abies alba) in the natural development of forest vegetation is confirmed up to the uppermost elevation (1 $259 \mathrm{~m})$ (Kučera 2012b). Equivalently, the occurrence of a natural Picea abies forest zone is not expected in the other adjacent mountain range of the Beskid Sądecki (Kučera 2012a), although development of a such altitudinal vegetation zone was presumed there by Pawłowski (1925) already above elevation $1100-1130 \mathrm{~m}$ and by Myczkowski - Grabski (1962) above (1000) 1050 or $1100 \mathrm{~m}$; Fabijanowski (1962) expected typical Picea forests even at altitudes $780 \mathrm{~m}$ and $915 \mathrm{~m}$.

\section{CONCLUSIONS}

According to the field research in the region of Vysoké skalky with data on the occurrence of Piceetum excelsae published by Kulczyński (1928) I conclude:

1. Almost all stands of Picea abies on the slopes of Vysoké skalky are plantations cultures unstable to environmental influences.

2. Only one local Picea abies stand (Figure 1: D, E) corresponds to the phytosociological data of Kulczyński (1928).

3. Data of altitudinal range of the occurrence of Picea stand corresponding to Kulczyński’s data published by Matuszkiewicz (1982), Pancer-Kotejowa et al. (1982, p. 319) and Szeląg (1995) are incorrect.

4. The plant community of the Kulczyński's Picea stand is not a native Picea abies woodland, and should probably be evaluated as a natural, isolated refugium of occurrence of a Picea abies population within a mixed forest stand.

5. Nature conservation should consider an appropriate management in respect of the preservation of this presumably unique gene pool of Picea abies in the Malé Pieniny.

Acknowledgements: My biggest thanks belong to Ing. Rastislav Rapant for his precious help during the field research. I would like to thank Mgr. Anna Petrášova (Matej Bel University in Banská Bystrica, Slovakia) for the determination of mosses and to RNDr. Dana Bernátová, CSc. (Botanical Garden of Comenius University, workplace Blatnica, Slovakia) for determination of herbarium specimen (BBZ). Also I am indebted to the Regionalna Dyrekcja Ochrony Środowiska w Krakowie (Wydział Ochrony Przyrody i Obszarów Natura 2000; Kraków, Poland) for kind permission to undertake the field research. This work was supported by the Slovak grant agency VEGA, project grant No. 2/0059/11, proofreading costs had to be paid privately by the author due to the regulations of his employer. 


\section{REFERENCES}

BARKMAN, J. J. - DOING, H. - SEGAL, S. (1964): Kritische Bemerkungen und Vorschläge zur quantitativen Vegetationsanalyse. Acta Bot. Neerl. 13: 394-419.

BRAUN-BlanQuet, J. (1951): Pflanzensoziologie. Grundzüge der Vegetationskunde. 2., umgearb. vermehr. Aufl. Springer, Wien. XII, 632 p.

FABIJANOWSKI, J. (1962): Zbiorowiska zlewni Białej Wody i ogólne wytyczne ich zagospodarovania [The forests of the Biała Woda basin and some general rules for their management]. Rocz. Nauk Roln., Ser. D. Monogr. 9: 113-148. (in Polish with English summary)

HENNEKENS, S. M. (2013): Turboveg for Windows. Ver 2.101. S. M. Hennekens, Wageningen. Comprehensive database management system designed for the storage, selection, and export of vegetation data (relevés). International single user version. ( 1998-2013 Stefan M. Hennekens. Available on internet: <http://www.synbiosys.alterra.nl/turboveg/>.

HENNEKENS, S. M. - SCHAMINÉE, J. H. J. (2001): Turboveg, a comprehensive database management system for vegetation data. J. Veg. Sci. 12: 589-591.

JANKOVSKÁ, V. (1991): Vývoj vegetačního krytu podtatranských kotlin od konce doby ledové po současnost [The development of the Vegetation Cover in inner Carpathians Basins of the Tatraforeland at the End of Glacial Period till the Present Time]. Zborn. Prác o Tatransk. Nár. Parku 31: 73-84. (in Czech with English, German, Polish and Russian summary).

JANKOVSKÁ, V. (1998): Pozdní glaciál a holocén podtatranských kotlin - obdoba sibiřské boreální a subboreální zóny? [Late Glacial and Early Holocene of Tatra's foreground basins: an analogy to Siberian boreal and subboreal zones?]. In: BENČAŤOVÁ, B. - HRIVNÁK, R. (eds). Rastliny a človek [Plants and human]. Technická univerzita vo Zvolene, Zvolen. 89-95. (in Czech with English abstract)

KRIPPEL, E. (1963): Postglaciálny vývoj lesov Tatranského národného parku [Postglacial development of the forests of the Tatra National Park]. Biol. Práce IX/5: 44 p. (in Slovak with Russian and German summary)

KRIPPEL, E. (1986): Postglaciálny vývoj vegetácie Slovenska [Postglacial development of the vegetation of Slovakia]. Veda, Bratislava. 312 p. (in Slovak with German summary)

KubinsKÁ, A. (ed.) - JANOVICOVÁ, K. (1998): Machorasty [Bryophytes]. In: MARHOLD, K. HINDÁK, F. (eds): Zoznam nižších a vyšších rastlín Slovenska [Checklist of non-vascular and vascular plants of Slovakia]. Veda, Bratislava. 297-331.

KUČERA, P. (2007): Západokarpatské smrečiny : Komentovaný literárny prehl'ad [Spruce woodlands of the Western Carpathians: A commented literature survey]. Botanická záhrada UK v Bratislave, pracovisko Blatnica, Blatnica. 222 p. Thesis. (in Slovak with English abstract)

KUČERA, P. (2010): Nomenclatural types of Picea abies syntaxa reported from Slovakia. Biologia (Bratislava) 65(5): 832-836. DOI: 10.2478/s11756-010-0103-x

KUČERA, P. (2011): Aconitum moldavicum, Calamagostis villosa, Cicerbita alpina, Dactylorhiza maculata, Epipactis palustris, Galium rotundifolium, Quercus cerris. In: ELIÁš P. ml. (ed.). Zaujímavejšie floristické nálezy. Bull. Slov. Bot. Spoločn. 33(2): 243-244.

KUČERA, P. (2012a): Vegetačný stupeň smrečín v Západných Karpatoch: rozšírenie a spoločenstvá [Norway spruce altitudinal vegetation zone in the Western Carpathians : distribution and communities]. Botanická záhrada UK v Bratislave, pracovisko Blatnica, Blatnica. 342 p. (in Slovak with English summary)

KUČERA, P. (2012b): Zhodnotenie údajov o rozšírení stupňa smrečín v Spišskej Magure a poznámky k výskytu jedlín [ Evaluation of data on the distribution of Norway spruce altitudinal vegetation zone in the Spišská Magura and comments to the occurence of Abies alba woodlands]. Nat. Tutela 16(1): 11-26. (in Slovak with Engslih abstract)

KUČERA, P. (2013): Horské bukové lesy v Západných Karpatoch. Veterné hole, skupina Hornej lúky [Montane beech forests in the Western Carpathians. The Veterné hole Mts, group of Mt. Horná lúka]. Nat. Carpatica. LIV: 17-34. (in Slovak with English abstract)

KUČERA, P. (2015): Štyri fytocenózy s bukom pod Štrbským plesom [Four phytocoenoses with beech below the Štrbské pleso]. Nat. Tutela 19: in press. (in Slovak with English abstract)

KUlCZYŃSKI, S. (1928): Die Pflanzenassoziationen der Pieninen. Bull. Int. Acad. Polon. Sci., Cl. Math., Sér. B., Sci. Nat. Suppl. II (1927): 57-203. 
MARHOld, K. (ed.) - GoliašovÁ, K. - HegedÜŠOVÁ, Z. - HodÁlOVÁ, I. - JuRKOVIČOVÁ, V. KMEŤOVÁ, E. - LETZ, R. - MichalKovÁ, E. - MrÁz, P. - PENiAŠTEKovÁ, M. - ŠíPOŠOVÁ, H. ŤAVODA, O. et al. (1998): Paprad'orasty a semenné rastliny [Ferns and Flowering Plants]. In: MARHOLD, K. - HINDÁK, F. (eds): Zoznam nižších a vyšších rastlín Slovenska [Checklist of nonvascular and vascular plants of Slovakia]. Veda, Bratislava. 333-687.

MatusZKIEWICZ, J. (1977): Pflanzensoziologische Übersicht der Waldgesellschaften von Polen. Teil 4. Die Fichten- und Tannen-Wälder. Phytocoenosis 6(3): 151-226. (in Polish with German summary)

MAtUSZKIEWICZ, J. M. (2002): Zespoły leśne Polski [Forest plant communities of Poland]. 1. wyd., dodruk. Wydawnictwo Naukowe PWN, Warszawa. (in Polish)

MATUSZKIEWICZ, W. (1982): Przewodnik do oznaczania zbiorowisk roślinnych Polski [Guide for the determination of plant communities of Poland]. Wyd. I. Dodruk do wyd. z r. 1981. Warszawa, Państwowe Wydawnictwo Naukowe. 300 p. (in Polish)

MATUSZKIEWICZ, W. (2014): Przewodnik do oznaczania zbiorowisk roślinnych Polski [Guide for the determination of plant communities of Poland]. Wyd. nowe (III. zm. I uzup.) - 9 dodruk. Warszawa, Wydawnictwo Naukowe PWN. 540 p. (in Polish)

MATUSZKIEWICZ, W. - MATUSZKIEWICZ, J. M. (1996): Przegląd fitosocjologiczny zbiorowisk leśnych Polski. (Synteza). [Pflanzensoziologische Übersicht der Waldgesellschaften von Polen (Synthese)]. Phytoceonosis (N. S.) 8(Semin. geobot. 3): 3-79. (in Polish with German summary)

MEDWECKA-KORNAŚ, A. (1959): Zespoły leśne i zaroślowe [Forest and scrub communities]. In: SZAFER, W. (red.) - MEDWECKA-KORNAŚ, A. - KORNAŚ, J. - PAWŁOWSKA, S. - PAWŁOWSKI, B. - ŚRodoń, A. -KozŁowskA, A.: Szata roślinna Polski I [Vegetation cover of Poland]. Państwowe wydawnictwo naukowe, Warszawa. 368-427.

MEDWECKA-KORNAŚ, A. (1972): Zespoły leśne i zaroślowe [Forest and scrub communities]. In: SZAFER, W. - ZARZYCKI, K. (red.) - MEDWECKA-KORNAŚ, A. - KORNAŚ, J. - PAWŁOWSKA, S. Poganowa, E. -PAwŁowski, B.- ŚRodoń, A. - KozŁowsKa, A.: Szata roślinna Polski [Vegetation cover of Poland]. I. 2. wyd., poprawione i uzupełnione. Państwowe wydawnictwo naukowe, Warszawa. 383-441.

MYCZKOWSKI, S. - GRABSKI, S. (1962): Zbiorowiska leśne Doliny Czarnej Wody w Beskidzie Sądeckim [The forest communities of the Czarna Woda torrent valley in the Beskid Sądecki Mountains]. Rocz. Nauk Roln., Ser. D. Monogr. 96: 149-191. (in Polish with English summary)

PANCER-Kotejowa, E. - BAZYLUK, W.- LiANA, A. (1982): Biocenozy leśne [Forest biocenoses]. In: ZARZYCKI, K. (red.) et al.: Przyroda Pienin w obliczu zmian [The nature of the Pieniny Mts. (West Carpathians) in face of the coming changes]. Państwowe Wydawnictwo Naukowe, Warszawa - Kraków. 315-328.

PaWŁOWsKi, B. (1925): Geobotaniczne stosunki Sądeczyzny. Prace Monogr. Komis. Fizjogr. I: 1-336. Pieninský národný park - Pieniński Park Narodowy [Pieniny National Park]. 2001. Vojenský kartografický ústav, š. p., Harmanec. 94 p. [recte 92], 1 map. (in Slovak and Polish)

SzELĄG, Z. (1995): Pieniny. Polish Bot. Stud., Guidebook Ser. 12: 151-165.

TICHÝ, L. (2002): JUICE, software for vegetation classification. J. Veg. Sci. 13: 451-453.

TICHÝ, L. (2013): JUICE. Ver. 7.0.68. L. Tichý, Brno [cit. 2012-09-04]. Program for analysis and classification of phytosociological tables and other quantitative ecological data sets. Freeware. () 1999-2010 L. Tichý. Available on internet: 〈http://www.sci.muni.cz/botany/juice/〉.

Weber, H. E. - Moravec, J. - Theurillat, J.-P. (2000): International Code of Phytosociological Nomenclature. 3rd ed. J. Veg. Sci. 11(5): 739-768.

WeSthOFF, V. - VAN DER MAAREL, E. (1973): The Braun-Blanquet Approach. In: TÜXEN, R. (ed. in chief ): Hadbook of Vegetation Science, Part V. Ordination and Classification of Communities (ed. Robert H. Whittaker). Dr. W. Junk b. v., The Hague. 617-726.

ZARZYCKI, K. (1981): Rośliny naczyniowe Pienin : Rozmieszczenie i warunki występowania [The vascular plants of the Pieniny Mts. (West Carpathians) : Distribution and habitats]. Państwowe Wydawnictwo Naukowe, Warszawa - Kraków. 260 p. (in Polish with English summary)

ZARZYCKI, K. (1982): Przegląd zbiorowisk roślinnych i ich siedlisk [Review of plant communities and their habitats]. In ZARZYCKI, K. (red.) et al.: Przyroda Pienin w obliczu zmian [The nature of the Pieniny Mts. (West Carpathians) in face of the coming changes]. Państwowe Wydawnictwo Naukowe, Warszawa - Kraków. 313-314, tab. 


\section{APPENDIX}

Phytosociological relevés recorded in the region of Vysoké skalky

Relevé No. 1: 49 $22.826^{\prime} \mathrm{N}, 20^{\circ} 33.360^{\prime} \mathrm{E}, \pm 6 \mathrm{~m}, 1023 \mathrm{~m}$ a.s.l. (upper limit), steep slope, aspect $\mathrm{NE}\left(46^{\circ}\right)$, relevé area $20 \times 20 \mathrm{~m}$, total cover $100 \%, \mathrm{E}_{3} 95 \%, \mathrm{E}_{2} 15 \%, \mathrm{E}_{1} 80 \%, \mathrm{E}_{0} 0 \%$, rocks $1 \%$, wood 0,5\%, Fagus trees above 80-100 years, Fagus perimeter ${ }_{1.3}$ [p.] 149 cm, height (h.) [29] m, age up to 80 years, 18. 7. 2011, P. Kučera, R. Rapant (PK220).

$\mathrm{E}_{3}$ : Fagus sylvatica 5, Acer pseudoplatanus 1, Picea abies 1,

$\mathrm{E}_{2}$ : Fagus sylvatica $2 \mathrm{~b}$, Corylus avellana $\mathrm{r}$,

$\mathrm{E}_{1}$ : Acer pseudoplatanus + , Fagus sylvatica + , Lonicera xylosteum r, Picea abies $\mathrm{r}$, Ribes alpinum $\mathrm{r}, R$. uva-crispa $\mathrm{r}$,

Lunaria rediviva 3, Galium odoratum 2b, Dryopteris filix-mas 1, Galeobdolon montanum 1, Geranium robertianum 1, Hordelymus europaeus 1, Hylotelephium argutum 1, Mercurialis perennis 1, Oxalis acetosella 1, Poa nemoralis 1, Roegneria canina 1 (det. D. Bernátová), Symphytum cordatum 1, Aconitum variegatum +, Actaea spicata + , Adoxa moschatellina +, Asarum europaeum +, Bromus benekenii + (det. D. Bernátová), Campanula trachelium +, Dentaria glandulosa +, Epilobium montanum +, Galeopsis speciosa +, Geranium sylvaticum +, Glechoma hirsuta + , Hypericum hirsutum + , Impatiens noli-tangere + , Lamium maculatum + , Lathyrus vernus + , Milium effusum + , Myosotis sp. + , Paris quadrifolia + , Polygonatum verticillatum +, Polystichum aculeatum +, Ranunculus platanifolius + , Rubus idaeus +, Senecio ovatus + , Silene dioica + , Stachys sylvatica + , Thalictrum aquilegiifolium + , Viola reichenbachiana + , Calamagrostis varia $\mathrm{r}$, Carduus personata $\mathrm{r}$, Cicerbita alpina $\mathrm{r}$, Cirsium erisithales r, Dryopteris carthusiana r, Petasites albus r, Primula elatior r, Ranunculus lanuginosus r, Salvia glutinosa r, Tithymalus amygdaloides r, Urtica dioica r, Veronica officinalis $\mathrm{r}$.

Relevé No. 2: $49^{\circ} 23.046^{\prime} \mathrm{N}, 20^{\circ} 33.163^{\prime} \mathrm{E}, \pm 8 \mathrm{~m}, 890 \mathrm{~m}$ a.s.1., aspect variable (NNW, $328^{\circ}$ ), total cover $100 \%, \mathrm{E}_{3} 45 \%, \mathrm{E}_{2} 20 \%, \mathrm{E}_{1} 93 \%, \mathrm{E}_{0} 20 \%$, fallen wood 1\%, age of Picea trees up to 80 r., Picea p. $96 \mathrm{~cm}$, h. [22] m, age up to cca 80 years, 17. 7. 2011, P. Kučera, R. Rapant (PK217).

$\mathrm{E}_{3}$ : Picea abies 3,

$\mathrm{E}_{2}$ : Picea abies 2b (in spots), Lonicera nigra 1, Fagus sylvatica +, Salix caprea +, Salix $\times$ subcaprea $\mathrm{r}$,

$\mathrm{E}_{1}$ Picea abies 2a, Lonicera nigra 1, Acer pseudoplatanus + , Fagus sylvatica + , Ribes petraeum + , Salix caprea + , Sorbus aucuparia + , Abies alba $\mathrm{r}$, Corylus avellana $\mathrm{r}$,

$\mathrm{E}_{1} \mathrm{~A}$ : Vaccinium myrtillus 4, Homogyne alpina 2b, Rubus idaeus 2a, Dryopteris dilatata 1 , Gymnocarpium dryopteris 1, Lycopodium annotinum 1, Maianthemum bifolium 1, Oxalis acetosella 1, Valeriana tripteris 1, Avenella flexuosa + , Calamagrostis villosa + , Luzula luzuloides + , L. sylvatica ssp. sylvatica + , Orthilia secunda + , Poa nemoralis + , Vaccinium vitis-idaea + , Deschampsia cespitosa $\mathrm{r}$, Urtica dioica $\mathrm{r}$,

$\mathrm{E}_{1}$ B: Agrostis capillaris +, Athyrium filix-femina + , Chrysosplenium alternifolium +, Fragaria vesca + , Gentiana asclepiadea + , Paris quadrifolia + , Senecio ovatus + , Alchemilla sp. r, Calamagrostis varia $\mathrm{r}$, Dentaria glandulosa $\mathrm{r}$, Geum rivale $\mathrm{r}$ (lower border of the relevé plot), Epilobium montanum r, Primula elatior r, Prunella vulgaris r, Streptopus amplexifolius r, Veronica officinalis $\mathrm{r}$,

$\mathrm{E}_{0}$ : Dicranum scoparium 2a, Polytrichum formosum 1, Sphagnum quinquefarium 1, Plagiochila porelloides + , Plagiomnium affine + , Plagiothecium denticulatum + , Tritomaria quinquedentata +, Calypogeia muelleriana +, Cephalozia bicuspidata +, Eurhynchium angustirete + , Lepidozia reptans + . 
Inside of the chosen relevé plot (of standard size $20 \times 20 \mathrm{~m}$ ) a slightly different microhabitat $\left(\mathrm{E}_{1} \mathrm{~B}\right.$, more wet and nutrient, with two fallen Picea trunks) fell within in the lower part of the plot.

Relevé No. 3: $49^{\circ} 23.031^{\prime} \mathrm{N}, 20^{\circ} 33.169^{\prime} \mathrm{E}, \pm 8 \mathrm{~m}, 900 \mathrm{~m}$ a.s.l., aspect variable (NNW, $347^{\circ}$ ), relevé area $15 \times 20 \mathrm{~m}$, total cover $100 \%, \mathrm{E}_{3} 40 \%, \mathrm{E}_{2} 18 \%, \mathrm{E}_{1} 90 \%, \mathrm{E}_{0} 10 \%$, fallen wood $2 \%$, Picea p. $121 \mathrm{~cm}$, h. [22,5] m, age up to 60-80 years, Fagus trees (at left bottom part) age up to 30 years, h. 6 (7) m, 17. 7. 2011, P. Kučera, R. Rapant (PK218).

$\mathrm{E}_{3}$ : Fagus sylvatica $2 \mathrm{~b}$, Picea abies $2 \mathrm{~b}$ (before disturbation 3 ),

$\mathrm{E}_{2}$ : Picea abies $2 \mathrm{a}$, Corylus avellana 1, Fagus sylvatica 1, Acer pseudoplatanus + , Sorbus aucuparia + , Abies alba $\mathrm{r}$,

$\mathrm{E}_{1}$ : Lonicera nigra 1, Picea abies 1, Acer pseudoplatanus + , Daphne mezereum + , Fagus sylvatica + , Rosa pendulina + , Salix $\times$ subcaprea + , Sorbus aucuparia + , Abies alba $\mathrm{r}$,

Vaccinium myrtillus 2b, Calamagrostis arundinacea 2a, Rubus idaeus 2a, Athyrium filixfemina 1, Calamagrostis varia 1, C. villosa 1, Dryopteris filix-mas 1, Galeobdolon montanum 1, Galium odoratum 1, Gentiana asclepiadea 1, Homogyne alpina 1, Oxalis acetosella 1, Senecio ovatus 1, Valeriana tripteris 1, Clematis alpina + , Dryopteris dilatata,+ Fragaria vesca +, Galium rotundifolium +, Gymnocarpium dryopteris +, Luzula luzuloides +, Maianthemum bifolium +, Mycelis muralis +, Prenanthes purpurea +, Rubus fruticosus agg. +, Agrostis capillaris r, Avenella flexuosa $\mathrm{r}$, Chamerion angustifolium r, Deschampsia cespitosa r, Epilobium montanum r, Hieracium sp. r, Hypericum maculatum r, Urtica dioica r, Vaccinium vitis-idaea $\mathrm{r}$, Veronica officinalis $\mathrm{r}$.

$\mathrm{E}_{0}$ : Eurhynchium angustirete 1, Dicranum scoparium 1, Barbilophozia barbata +, Plagiochila porelloides + , Plagiomnium affine + Sphagnum quinquefarium + .

Relevé No. 4: 49²2.999’ N, 20³32.208' E, \pm 14 m, 927 m a.s.l., gentle slope, aspect NNE $\left(27^{\circ}\right)$, relevé area $20 \times 20 \mathrm{~m}$, total cover $98 \%, \mathrm{E}_{3} 70 \%, \mathrm{E}_{2} 25 \%, \mathrm{E}_{1} 75 \%$, bryophytes only on rocks, rocks 8\%, Fagus trees (up to) 60-80 years, Fagus h. above $20 \mathrm{~m}$ (also Acer), age up to 70-80 years, 17. 7. 2011, P. Kučera, R. Rapant (PK219).

$\mathrm{E}_{3}$ : Fagus sylvatica 4 , Acer pseudoplatanus $2 \mathrm{~b}$, Picea abies 1 ,

$\mathrm{E}_{2}$ : Corylus avellana $2 \mathrm{~b}$, Fagus sylvatica $2 \mathrm{a}$, Lonicera nigra + ,

$\mathrm{E}_{1}$ : Fagus sylvatica (1) 2a, Acer pseudoplatanus 1, Fraxinus excelsior + , Lonicera nigra + , Picea abies +, Rosa pendulina +, Abies alba r, Sambucus racemosa r, Sorbus aucuparia r, Viburnum opulus $\mathrm{r}$,

$\mathrm{E}_{1}$ : Galium odoratum 2b, Dryopteris filix-mas 2a, Calamagrostis varia 1, Galeobdolon montanum 1, Melica nutans 1, Oxalis acetosella 1, Rubus fruticosus agg. 1, Vaccinium myrtillus 1, Valeriana sambucifolia 1 (det. D. Bernátová), Brachypodium sylvaticum +, Calamagrostis arundinacea + , Chaerophyllum hirsutum + , Clinopodium vulgare,+ Cruciata glabra +, Dentaria glandulosa +, Epilobium montanum +, Festuca sp. +, Fragaria vesca +, Galium anisophyllon +, Hordelymus europaeus +, Hypericum maculatum +, Luzula luzuloides +, Maianthemum bifolium +, Mycelis muralis +, Paris quadrifolia +, Poa nemoralis + , Polypodium vulgare + , Polystichum aculeatum + , Prenanthes purpurea +, Primula elatior + , Ranunculus platanifolius + , Rubus idaeus + , Sanicula europaea + , Senecio ovatus + , Valeriana tripteris + , Viola reichenbachiana + , Ajuga reptans $\mathrm{r}$, Athyrium filixfemina r, Epipactis helleborine r, Hylotelephium maximum r, Polygonatum verticillatum r, Urtica dioica $\mathrm{r}$, Veronica chamaedrys $\mathrm{r}$.

Outside of the relevé plot at the slope beginning down from this lateral ridge: Lonicera xylosteum, Ribes alpinum. 


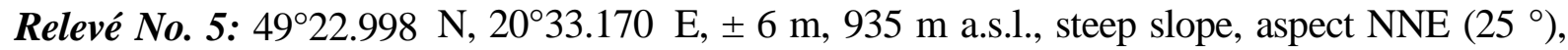
relevé area $20 \times 20 \mathrm{~m}$, total cover $100 \%, \mathrm{E}_{3} 40 \%$ (formerly above $75 \%$ ), $\mathrm{E}_{2} 55 \%, \mathrm{E}_{1} 80 \%$, $\mathrm{E}_{0}$ cca $15 \%$, Fagus tree probably above 80 years, h. 16-17 m, Picea trees were up to 60-80 years old, most of them are dead, Picea h. above $20 \mathrm{~m}(21-22 \mathrm{~m}), 18.7 .2011$, P. Kučera, R. Rapant (PK223).

$\mathrm{E}_{3}$ : Picea abies 3, Fagus sylvatica 2a (2b), Abies alba 1 (young), Acer pseudoplatanus 1 (young),

$\mathrm{E}_{2}$ : Lonicera nigra 3, Corylus avellana 2a, Fagus sylvatica 2a, Picea abies 2a, Sorbus aucuparia ssp. aucuparia 1, Abies alba + , Acer pseudoplatanus + ,

$\mathrm{E}_{1}$ (partly mixed types): Picea abies 2a, Lonicera nigra 1, Abies alba +, Acer pseudoplatanus + , Fagus sylvatica + , Ribes alpinum + , Sorbus aucuparia + , Corylus avellana $\mathrm{r}$, Salix silesiaca $\mathrm{r}$,

Vaccinium myrtillus 3, Galium odoratum 2a, Gymnocarpium dryopteris 2a, Calamagrostis varia 1, Dryopteris dilatata 1, Hordelymus europaeus 1, Galeobdolon montanum 1, Oxalis acetosella 1, Rubus idaeus 1, Vaccinium vitis-idaea 1, Valeriana tripteris 1 , Asplenium viride + , Athyrium filix-femina + , Chamerion angustifolium + , Dentaria glandulosa + , Dryopteris filix-mas + , Epilobium montanum + , Fragaria vesca + , Maianthemum bifolium + , Petasites albus + , Phegopteris connectilis + , Poa nemoralis + , Polystichum aculeatum +, Senecio ovatus + , Pyrethrum clusii + , Viola reichenbachiana + , Avenella flexuosa $\mathrm{r}$, Carex digitata r, Clematis alpina r, Cystopteris fragilis r, Hieracium sp. r, Hypericum maculatum r, Mercurialis perennis r, Ranunculus platanifolius r, Sanicula europaea r, Streptopus amplexifolius $\mathrm{r}$, Urtica dioica $\mathrm{r}$,

$\mathrm{E}_{0}$ : Rhizomnium punctatum 1, Eurhynchium angustirete 1, Dicranum scoparium 1, Blepharostoma trichophyllum +, Calypogeia muelleriana +, Cephalozia bicuspidata +, Lepidozia reptans +, Lophozia ventricosa +, Plagiochila asplenioides +, Polytrichum formosum + , Sphagnum quinquefarium + , Tetraphis pellucida + .

Relevé No. 6: $49^{\circ} 22.996^{\prime} \mathrm{N}, 20^{\circ} 33.143^{\prime} \mathrm{E}, \pm 5 \mathrm{~m}, 940 \mathrm{~m}$ a.s.1., slope variable (total [40] ${ }^{\circ}$ ), aspect $\mathrm{N}\left(350^{\circ}\right)$, relevé area $20 \times 20 \mathrm{~m}$, total cover 97\%, $\mathrm{E}_{3}(68 \%), \mathrm{E}_{2}(35 \%), \mathrm{E}_{1}(40 \%)$, $\mathrm{E}_{0}(35 \%$ everywhere on rocks), Fagus h. even $20 \mathrm{~m}$, Picea h. above $20 \mathrm{~m}, 18$. 7. 2011, P. Kučera, R. Rapant (PK222).

$\mathrm{E}_{3}$ : Fagus sylvatica 4 , Picea abies $2 \mathrm{~b}$ [formerly 3],

$\mathrm{E}_{2}$ : Lonicera nigra $2 \mathrm{~b}$, Ribes alpinum 2a, Corylus avellana 1, Picea abies 1 , Salix caprea 1 , Sambucus racemosa 1, Sorbus aucuparia + , Lonicera xylosteum r, Salix $\times$ subcaprea $\mathrm{r}$,

$\mathrm{E}_{1}$ : Sambucus racemosa 1 , Ribes alpinum 1 , Lonicera nigra 1 , Sorbus aucuparia + , Rosa pendulina + , Acer pseudoplatanus + , Picea abies $\mathrm{r}$, Abies alba $\mathrm{r}$,

Gymnocarpium dryopteris 2a, Oxalis acetosella 2a, Geranium robertianum 2a, Dryopteris filix-mas 1, Galeobdolon montanum 1, Galium odoratum 1, Rubus idaeus 1, Urtica dioica 1, Vaccinium myrtillus 1, Athyrium filix-femina +, Brachypodium sylvaticum +, Cardamine flexuosa + , Cystopteris fragilis + , Dryopteris dilatata + , Epilobium montanum + , Fragaria vesca + , Hylotelephium argutum + , Luzula luzuloides + , Paris quadrifolia + , Poa nemoralis + , Polypodium vulgare + , Polystichum aculeatum + , Senecio ovatus + , Valeriana tripteris +, Actaea spicata r, Asplenium trichomanes $\mathrm{r}$, A. viride r, Cardaminopsis arenosa $\mathrm{r}$, Dentaria glandulosa r, Dryopteris expansa r, Valeriana sambucifolia $\mathrm{r}$.

Relevé No. 7: 49²2.993' N, 20³3.053' E, \pm 5 m, 932 m a.s.l., gentle slope, aspect NNW/N $\left(348^{\circ}\right)$, relevé area $20 \times 20 \mathrm{~m}$, total cover $97 \%, \mathrm{E}_{3} 68 \%, \mathrm{E}_{2} 2 \%, \mathrm{E}_{1} 95 \%, \mathrm{E}_{0}$ cca $15 \%$, wood 5\%, Picea trees 60-80 years, Picea p. 129 cm, h. [25,5] m, age 60-80 r., 18. 7. 2011, P. Kučera, R. Rapant (PK221). 
$\mathrm{E}_{3}$ : Picea abies 4 , Larix decidua $\mathrm{r}$,

$\mathrm{E}_{2}$ : Fagus sylvatica + , Acer pseudoplatanus $\mathrm{r}$, Fraxinus excelsior $\mathrm{r}$, Lonicera nigra $\mathrm{r}$,

$\mathrm{E}_{1}$ : Fagus sylvatica 1, Acer pseudoplatanus +, Fraxinus excelsior +, Abies alba r, Lonicera nigra r, Sambucus racemosa r, Sorbus aucuparia r,

Rubus idaeus 3, Senecio ovatus 3, Oxalis acetosella 2b, Galeobdolon montanum 2a, Asarum europaeum 1, Athyrium filix-femina 1, Dryopteris dilatata 1, D. filix-mas 1, Galium rotundifolium 1, Geranium robertianum 1, Lysimachia nemorum 1 (det. D. Bernátová), Adoxa moschatellina +, Cardamine flexuosa + (det. D. Bernátová), Festuca gigantea +, Galium odoratum + , Mercurialis perennis + , Mycelis muralis + , Poa nemoralis + , Primula elatior + , Silene dioica + , Urtica dioica + , Viola reichenbachiana + , Actaea spicata $r$, Chamerion angustifolium r, Epilobium montanum r, Fragaria vesca r, Hylotelephium argutum r, Platanthera bifolia r, Prenanthes purpurea r, Roegneria canina $\mathrm{r}$ (det. D. Bernátová), Salvia glutinosa $\mathrm{r}$.

$\mathrm{E}_{0}$ : Brachythecium reflexum 1, B. starkei 1, Rhizomnium punctatum 1, Dicranum scoparium + , Plagiothecium denticulatum + , Plagiomnium affine + . 